\title{
Effects of conditioning temperature and time during the pelleting process on feed molecular structure, pellet durability index, and metabolic features of co-products from bio-oil processing in dairy cows
}

\author{
Xuewei Huang, ${ }^{*}$ Colleen Christensen, ${ }^{*}$ and Peiqiang $\mathrm{Yu}^{*}{ }^{1}$ \\ *Department of Animal and Poultry Science, University of Saskatchewan, 51 Campus Drive, Saskatoon, SK, S7N 5A8 \\ †College of Animal Science and Veterinary Medicine, Tianjin Agricultural University, Tianjin, China
}

\begin{abstract}
The objectives of this study were to systematically determine effects of conditioning temperature $(70,80$, and $90^{\circ} \mathrm{C}$ ), time (50 and $75 \mathrm{~s}$ ), and interaction (temperature $\times$ time) during the pelleting process on co-products from bio-oil processing (canola meal) in terms of processinginduced changes on (1) protein molecular structure, (2) pellet durability index, (3) detailed chemical profile, (4) metabolic features and fractions of protein and carbohydrate, (5) total digestible nutrients and energy values, and (6) rumen degradable and undegradable content. Pellet durability was increased with increasing conditioning time. Chemical and carbohydrate profiles of co-products were not altered by pelleting process under different conditioning temperatures and times. With regard to protein fraction profiles, pellets conditioned for $50 \mathrm{~s}$ had higher soluble crude protein (SCP) and lower neutral detergent insoluble crude protein (NDICP) contents than those conditioned for $75 \mathrm{~s}(21.7$ vs. $20.1 \%$ SCP, 16.0 vs. $16.5 \%$ NDICP, respectively). Total digestible nutrients and energy values were not altered by processing. Samples conditioned for $50 \mathrm{~s}$ had a higher content of rapidly degradable protein fraction (PA2) than those conditioned for 75 s (21.7 vs. 21.1\% crude protein). In addition, the slowly degradable true protein fraction (PB2) was affected by the interaction of conditioning temperature and time. However, carbohydrate fractions did not differ with different conditioning temperatures and time. Different temperatures and time of conditioning during pelleting process greatly affect protein profiles without altering carbohydrate profiles. Molecular structure analyses also showed that pelleting altered inherent protein molecular structures of the co-products from bio-oil processing. Future study is needed to detect how molecular structure changes affect nutrient availability in dairy cattle.
\end{abstract}

Received December 29, 2014.

Accepted March 16, 2015.

${ }^{1}$ Corresponding author: peiqiang.yu@usask.ca
Key words: pelleting, conditioning temperature and time, nutrient utilization and availability, molecular structure

\section{INTRODUCTION}

Pelleting is a process that uses moisture, heat, and pressure to agglomerate smaller particles into larger particles (Skoch et al., 1981; Falk, 1985). Its proven benefits include improved palatability and hygienic condition of feed, increased feed bulk density and flowability, elimination of segregation problems, and improved transportation efficiency. Pelleting also affects the metabolic and digestion characteristics of feeds (Thomas and van der Poel, 1996; Abdollahi et al., 2013). However, the interrelations between conditioning, pelleting, and cooling should be considered when evaluating the effects of the pelleting process on feed materials (Thomas et al., 1997). It is also important to understand how the inherent structure of feed is affected by pelleting under different conditioning temperatures and times, and how pelleting-induced structural changes affect nutrient profiles and availability in dairy cattle (e.g., energy value, protein and carbohydrate fractions, true nutrient supply in rumen and small intestine; Yu, 2010).

To date, limited information is available about the effects of conditioning temperature, time, and their interaction of pelleting process on internal protein structure changes at the molecular level in relation to nutrient utilization and availability in dairy cattle. The objectives of this study were to systematically determine effects of conditioning temperature $\left(70,80\right.$, and $\left.90^{\circ} \mathrm{C}\right)$, time (50 and $75 \mathrm{~s}$ ), and their interaction (temperature $\times$ time) during the pelleting process on co-products from bio-oil processing (canola meal as model feed) in terms of processing-induced changes on (1) protein molecular structure, (2) pellet durability index, (3) detailed chemical profiles, (4) metabolic features and fractions of protein and carbohydrate, (5) total digestible nutrients and energy values, and (6) rumen degradable and undegradable content in dairy cattle. 


\section{MATERIALS AND METHODS}

\section{Sample Preparation, Pelleting Process, and Pellet Durability Test}

The co-products from bio-oil processing of canola meal as model feeds were used in this study to investigate the effect of conditioning temperature, time, and their interaction of pelleting process on internal protein structure changes on a molecular level in relation to nutrient utilization and availability in dairy cattle. Two representative sources of co-products were obtained from a commercial feed company (Federated Cooperatives Ltd., Saskatoon, SK, Canada) with different manufacturing dates. A California laboratory pellet mill (NH-397202, California Pellet Mill Co., Crawfordsville, IN) with a capacity of $20 \mathrm{~kg} / \mathrm{h}$ was used to produce canola meal pellets. The conditioning temperature $\left(70,80\right.$, and $\left.90^{\circ} \mathrm{C}\right)$ was set with heating pads wrapped around the conditioning chamber and maintained by using an Omega CN350 controller (Omega Engineering Inc., Stamford, CT). The temperature of the conditioned mash was measured at the outlet of the conditioner continuously by an Omega HH-25TC thermometer. Conditioning time was determined by changing the flowrate at which the canola meal entered the conditioner. The conditioning time was determined by placing colored materials into the conditioner, then measuring time until the materials exited the conditioner. At dial settings of " 24 " and " 30 " on the pelleting machine, the production rates were 250 and $814 \mathrm{~g} / \mathrm{min}$, respectively; and related transition time of materials in the conditioner were 75 and $50 \mathrm{~s}$, respectively. Steam was injected at $1.0 \mathrm{~kg} / \mathrm{h}$ at $248.2 \mathrm{kPa}$ during the conditioning stage. A pellet die with a hole diameter of $6.4 \mathrm{~mm}$ and a thickness of $44 \mathrm{~mm}$ was used. Pellets were cooled before the pellet durability test by exposing pellets to the air for $24 \mathrm{~h}$. This resulted in a total of 12 treatment samples ( 3 temperatures $\times 2$ times $\times$ 2 different batches).

Pellet durability was presented as a pellet durability index (PDI), which was measured using the "Pfost" method and expressed on a percentage basis (Thomas and van der Poel, 1996). Around $500 \mathrm{~g}$ of sieved pellets was put in a drum with specified dimensions $(30.5 \times$ $30.5 \times 12.7 \mathrm{~cm}$ ) and tumbled for $10 \mathrm{~min}$ at $50 \mathrm{rpm}$. After tumbling, the pellets were screened with a sieve (US Sieve Size 6 with $3.36 \mathrm{~mm}$ diameter) to determine the pellets that could not pass through the sieve. The PDI was calculated as follows (Thomas and van der Poel, 1996):

$$
\begin{aligned}
& \mathrm{PDI}=\text { (weight of pellets before tumbling) } / \\
& \text { (weight of pellets after tumbling }) \times 100 \% \text {. }
\end{aligned}
$$

\section{Pelleting-Induced Changes in Chemical Profiles}

For chemical analysis, all samples were ground through a 1-mm screen using a Retsch ZM 200 Rotor mill (Rose Scientific Ltd., Edmonton, AB, Canada). Dry matter, ash, ether extract (EE), and $\mathrm{CP}$ were analyzed according to AOAC (1990) official methods 930.15, 942.05, 954.02, and 984.13, respectively. The methods described in Van Soest et al. (1991) combined with an Ankom A200 filter bag technique (Ankom Technology Corp., Fairport, NY) were used to determine ADF, NDF, and ADL in the samples. Adjusted NDF was determined when sodium sulfite was added together with heat-stable amylase before neutral detergent extraction. The methods in Licitra et al. (1996) were applied to analyze acid detergent insoluble CP (ADICP) and neutral detergent insoluble CP (NDICP). All samples were incubated with a bicarbonate-phosphate buffer, and then filtered through Whatman \#54 filter papers to determine the total soluble CP (SCP) content (Roe et al., 1990). The method used to determine NPN was in accordance with Licitra et al. (1996), in which tungstic acid is used to precipitate the true protein fraction and then the difference between total $\mathrm{CP}$ and precipitated $\mathrm{CP}$ is considered the NPN.

\section{Pelleting-Induced Changes in Energy Values}

Summative approaches from the National Research Council (NRC, 2001) dairy were used to estimate values of total digestible (td) NFC (tdNFC), total digestible $\mathrm{CP}$ (tdCP), total digestible NDF (tdNDF), total digestible FA (tdFA), TDN at $1 \times$ maintenance $\left(\mathbf{T D N}_{1 \times}\right)$, TDN at $3 \times$ maintenance $\left(\mathbf{T D N} \mathbf{N}_{3 \times}\right)$, digestible energy $(\mathbf{D E})$ at $1 \times$ maintenance $\left(\mathbf{D E}_{1 \times}\right)$, DE at a production level of $3 \times$ maintenance $\left(\mathbf{D E}_{\mathbf{p} 3 \times}\right)$, $\mathrm{ME}$ at a production level of $3 \times$ maintenance $\left(\mathbf{M E}_{\mathbf{p} 3 \times}\right)$, and net energy at a production level of $3 \times$ maintenance $\left(\mathrm{NE}_{\mathrm{Lp} 3 \times}\right)$. The methods to determine $\mathrm{ME}, \mathrm{NE}_{\mathrm{M}}$, and $\mathrm{NE}_{\mathrm{G}}$ were in accordance with NRC (1996).

\section{Pelleting-Induced Changes in Protein and Carbohydrate Fractions}

In this study, the Cornell Net Carbohydrate and Protein System (CNCPS, version 6.1; Van Amburgh et al., 2010) was applied to partition the CP and carbohydrate (CHO) fractions (Van Amburgh et al., 2010; Higgs et al., 2012). In CNCPS version 6.1, protein fractions are profiled based on their ruminal degradation characteristics: ammonia (PA1), nonammonia soluble true protein (PA2), moderately degradable true protein (PB1), slowly degradable true protein (PB2), and completely undegradable CP (PC; Higgs et al., 
2012; Van Amburgh et al., 2010, 2013). Fraction PA1 degrades at $200 \% / \mathrm{h}$; PA2 degrades at 10 to $40 \% / \mathrm{h}$; $\mathrm{PB} 1$ contains neutral detergent soluble protein and degrades at 3 to $20 \% / \mathrm{h}$; PB2 contains proteins that bind in fiber and slowly degrades at 4 to $9 \% / \mathrm{h}$ in forages. The CHO fraction scheme is expanded into 8 fractions: VFA (CA1), lactate (CA2), organic acids (CA3), sugars (CA4), starch (CB1), soluble fibers (CB2), slowly degradable and available NDF (CB3), and lignin (CC). Fraction CA2 degrades at 7\%/h, CA3 degrades at $5 \% / \mathrm{h}$, and CA4 degrades at 40 to $60 \% / \mathrm{h}$; CB1 is starch and degrades at 20 to $40 \% / \mathrm{h}, \mathrm{CB} 2$ degrades at 20 to $40 \% / \mathrm{h}$, and CB3 has a degradation rate of 4 to $9 \% /$ h. Fractional degradation and passage rates were obtained from the CNCPS feed library and literature (Tylutki et al., 2008; Van Amburgh et al., 2010; Higgs et al., 2012). In canola meal, CA1, CA2, and CA3 are not present, and only a small amount of CB1 (5\%) was found (Newkirk, 2009). The CHO fractions of interest in this study were CA4, CB2, CB3, and CC (Newkirk, 2009). Fractions of rumen degradable and undegradable protein and carbohydrate were calculated as well.

Models in CNCPS version 6.1 become more sensitive to feeds with high levels of protein and carbohydrates (Higgs et al., 2012; Van Amburgh et al., 2010, 2013). In soluble pools, to obtain a more appropriate reflection of cattle biology, re-assignation of the liquid passage rate equations to $\mathrm{CHO} \mathrm{CA}, \mathrm{PA}$, and $\mathrm{PB}$ has been made (Van Amburgh et al., 2010). The resultant higher predicted outflow of soluble components would reduce estimated microbial yield and ammonia production (Van Amburgh et al., 2010).

\section{Detection of Molecular Structure Changes}

Pelleting-induced changes in the protein and carbohydrate fractions of co-products from bio-oil processing were detected using advanced molecular spectroscopy with attenuated total reflectance Fourier transform infrared spectroscopy (ATR-FT/IR). The ATR-FT/ IR analyses with chemometrics were performed at the molecular spectroscopy laboratory of the Department of Animal and Poultry Science, University of Saskatchewan (Saskatoon, SK, Canada) using an AJasco FT/ IR-4200 (Jasco Corp., Tokyo, Japan). The ATR-FT/ IR machine was equipped with a ceramic infrared light source and a deuterated L-alanine-doped triglycine sulfate detector that contains an MI Racle attenuated total reflectance (ATR) accessory module and outfitted with a ZnSe crystal and pressure clamp (Pike Technologies, Madison, WI). Spectra were collected at the midinfrared region from approximately 4,000 to $700 \mathrm{~cm}^{-1}$ with a spectral resolution of $4 \mathrm{~cm}^{-1}$ with 128 scans co-added. To minimize infrared absorption by $\mathrm{CO}_{2}$ and water vapor in the ambient air, background spectra were collected with 256 scans. Jasco Spectra manager II software was used to collect spectral data. Spectral data of each sample was collected 5 times. Omnic 7.3 (Thermo-Nicolet, Madison, WI) software was used to identify and collect spectral information of functional groups of protein, cellulosic components, and carbohydrate.

\section{Univariate Molecular Structure Analysis}

Spectral bands of functional groups were detected based on the literature (Theodoridou and Yu, 2013a; Xin and Yu, 2013a,b; Yang et al., 2013b; Peng et al., 2014a,b). When identifying the secondary structure of protein, the baseline was set at $\sim 1,718$ to $1,481 \mathrm{~cm}^{-1}$. Amide I consists of $80 \% \mathrm{C}=\mathrm{O}$ stretching vibrations and $20 \% \mathrm{C}-\mathrm{N}$ stretching vibrations; amide II consists of $60 \% \mathrm{~N}-\mathrm{H}$ bending vibrations and $40 \%$ stretching vibrations (Jackson and Mantsch, 1995, 2000; Yu, 2004). Band absorption selection of amide I, amide II, $\alpha$-helix, and $\beta$-sheet was determined based on previous studies as showed in Figure 1 (Jackson and Mantsch, 1995, 2000; Yu, 2004; Xin and Yu, 2013b; Yang et al., 2013b). Therefore, for protein amide I, peak center ranged from $\sim 1,644$ to $1,625 \mathrm{~cm}^{-1}$ and area ranged from $\sim 1,718$ to $1,567 \mathrm{~cm}^{-1}$. For protein amide II, peak center ranged from $\sim 1,538$ to $1,535 \mathrm{~cm}^{-1}$ and area ranged from $\sim$ 1,567 to $1,481 \mathrm{~cm}^{-1}$. Amide I and amide II are 2 major bands associated with the protein secondary structure (Yu, 2004). However, amide I, rather than amide II, is the first band used when studying the protein secondary structure. This is because amide II is affected by multiple functional groups, which lead to complex vibrations; therefore, amide II has a lower sensitivity when predicting protein secondary structure (Jackson and Mantsch, 2000). Amide I can be further divided into several multi-component peaks using the second derivative function in Omnic 7.3. The $\alpha$-helix and $\beta$-sheet were then selected from these multi-components. The $\alpha$-helix peak center was located at $\sim 1,660-1,650 \mathrm{~cm}^{-1}$ and $\beta$-sheet peak center was located at $\sim 1,627-1,618$ $\mathrm{cm}^{-1}$.

\section{Statistical Analysis}

This study was designed using a randomized complete block design with a $3 \times 2$ factorial treatment arrangement. Statistical analyses were performed using the MIXED procedure of SAS 9.3 (SAS Institute Inc., Cary, NC). The following model was used: $Y_{i j r l}=\mu+$ $\alpha_{i}+\beta_{j}+\gamma_{k}+S_{r}+e_{i j r l}$, in which $Y_{i j l l}$ was an observation of the dependent variable ijrl, $\mu$ was the population mean for the variable, $\alpha_{i}$ was the effect of condi- 

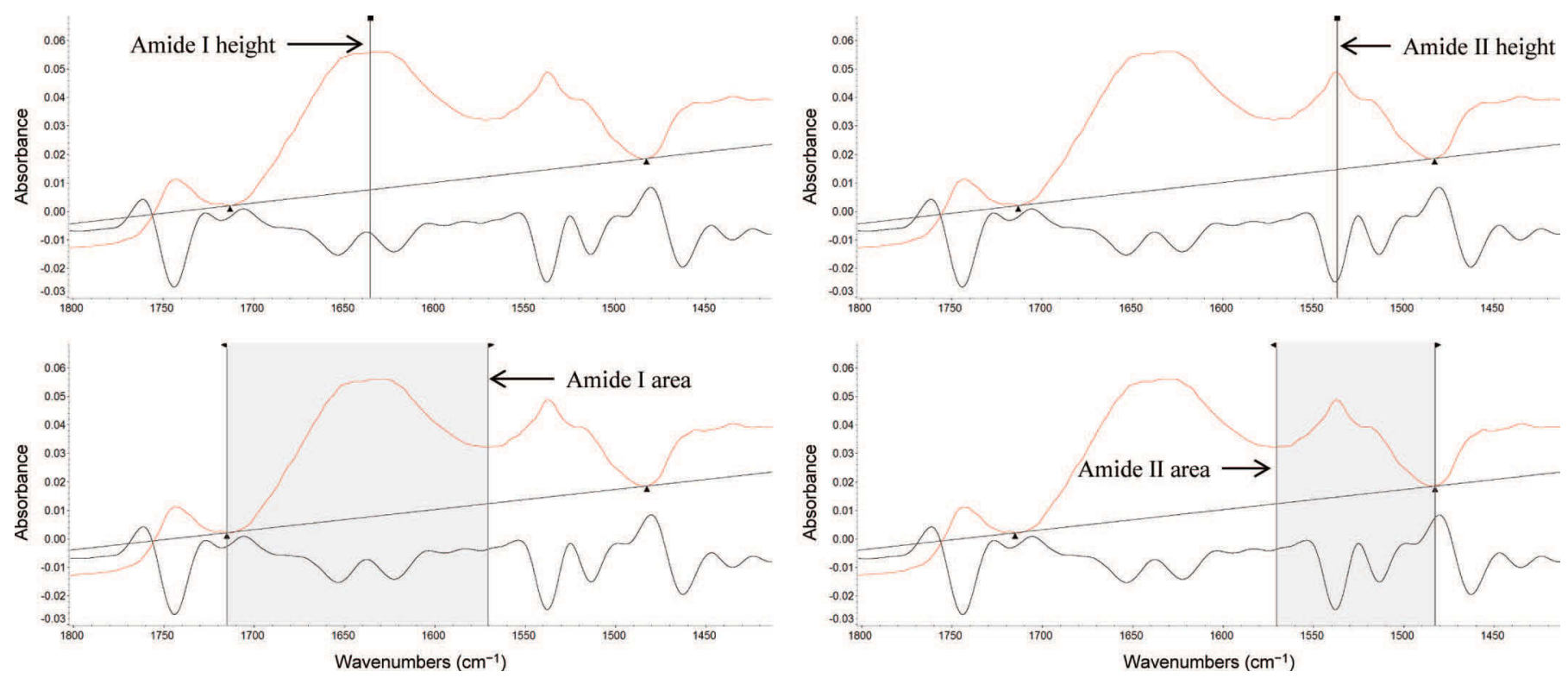

Figure 1. Typical Fourier transform infrared spectrum for co-products from bio-oil processing at the regions of protein $\left(\sim 1,718-1,481 \mathrm{~cm}^{-1}\right)$. Color version available online.

tioning temperature, $\beta_{j}$ was the effect of conditioning time, $\gamma_{k}$ was the interaction of conditioning time and temperature, $S_{r}$ was the effect of sources as a random effect $\left(\gamma_{k}=\alpha_{i} \times \beta_{j}\right)$, and $e_{i j r l}$ was the random error associated with observation ijrl. A contrast statement was performed to detect the difference between the unprocessed mash and pellets. Also, polynomial contrasts (linear and quadratic) of conditioning temperature $(70$, 80 , and $90^{\circ} \mathrm{C}$ ) were determined if the linear effect of conditioning temperature was significant. The significant level for all statistical analyses was declared at $P$ $<0.05$ and trends at $P<0.10$. Treatment means were compared using the Tukey-Kramer method.

\section{RESULTS AND DISCUSSION}

\section{Effects of Conditioning Temperature and Time on PDI}

Shearing and abrasion happen during pellet manufacturing. This can damage pellets, potentially turning them into mash. Hence, pellets must have sound resistance against stress during transportation and distribution (Thomas and van der Poel, 1996). The results of pellet durability tests are shown in Table 1. The interaction of conditioning temperature and time on PDI of canola meal pellets was not significant. The PDI of canola meal pellets was not affected by conditioning temperature but was positively affected by conditioning time $(P<0.05)$. Samples conditioned for $75 \mathrm{~s}$ had a higher PDI than those conditioned for $50 \mathrm{~s}(91.32$ vs. $73.37 \%)$. Previous studies indicated that increasing conditioning time would improve PDI (Thomas and van der Poel, 1996; Thomas et al., 1997; Abdollahi et al., 2013). Abdollahi et al. (2013) indicated that pellet quality would be improved if diets contained a high level of protein. Increasing the retention time of mash feed in the conditioner, along with injection of steam, contributed to the forming of hydrogen bonds between hydrophilic portions of protein and water molecules (Abdollahi et al., 2013). In addition, longer conditioning time could take advantage of the increased thermo-mechanical nutrient interaction and enhanced feed adhesion to improve pellet durability (Fairchild and Greer, 1999; Moritz and Lilly, 2010; Abdollahi et al., 2013).

\section{Effects of Conditioning Temperature and Time on Chemical Profiles}

Table 2 shows the effects of pelleting under different conditions on the chemical profiles of canola meal. The interaction of conditioning temperature and time was not significant on the basic chemical profiles. The conditioning temperature and time did not exhibit a significant effect on basic chemical profiles (ash, DM, and EE). For carbohydrate profiles, NDF (30.5\% DM), $\operatorname{ADF}(19.4 \% \mathrm{DM})$, and ADL $(8.1 \% \mathrm{DM})$ were not affected by conditioning temperature, time, or their interaction. Total CP content of canola meal pellets with an average $39.9 \%$ DM was not affected by conditioning temperature and time. Samadi and Yu (2011) reported 
Table 1. Effects of temperature and time of conditioning during the pelleting process on pellet durability index (PDI) in co-products (canola meal) from bio-oil processing

\begin{tabular}{|c|c|c|c|c|c|c|c|c|c|c|c|c|}
\hline \multirow[b]{2}{*}{ Item } & \multicolumn{3}{|c|}{ Temperature $(\mathrm{T})$} & \multirow[b]{2}{*}{ SEM } & \multicolumn{2}{|c|}{ Time $(\mathrm{t})$} & \multirow[b]{2}{*}{ SEM } & \multicolumn{3}{|c|}{$P$-value } & \multicolumn{2}{|c|}{$\begin{array}{l}\text { Polynomial contrast } \\
\text { for T ( } P \text {-value })\end{array}$} \\
\hline & $70^{\circ} \mathrm{C}$ & $80^{\circ} \mathrm{C}$ & $90^{\circ} \mathrm{C}$ & & $50 \mathrm{~s}$ & $75 \mathrm{~s}$ & & $\mathrm{~T}$ & $\mathrm{t}$ & $\mathrm{T} \times \mathrm{t}$ & Linear & Quadratic \\
\hline
\end{tabular}

${ }^{\mathrm{x}, \mathrm{y}}$ Means with different letters in the same row are significantly different $(P<0.05)$.

that heating methods would not influence total CP content. McKinnon et al. (1995) indicated that the total CP content did not change when processing under different heating temperatures and time. However, we observed that conditioning time had significant effects on SCP $(P<0.05)$ and NDICP $(P<0.01)$. Samples conditioned for $75 \mathrm{~s}$ had a lower SCP content and a higher NDCIP content than those conditioned for 50 s. However, the unprocessed mash was different from the pelleted samples $(P<0.05)$ with higher NDICP. Goelema (1999) reported that heating could stabilize protein structure and create crosslinks between proteins and carbohydrates. In addition, protein is very sensitive to environmental temperature. Any change in temperature that is able to affect the noncovalent interaction in protein structure may induce changes in the quaternary, tertiary, or secondary structures of the protein (Goelema, 1999). Both processing temperature and processing time during heat treatment play important roles in determining the level of denaturation and degradation of protein (Goelema, 1999). During the conditioning stage, increasing conditioning time not only hydrates the materials but also reduces friction when they are passed through the pellet die (Thomas et al., 1997; Abdollahi et al., 2013). The ideal heating treatment was able to increase NDICP, reduce SCP of feed, and minimize the increase in ADICP at the same time (Van Soest, 1989). McKinnon et al. (1995) observed that reduced SCP and increased NDICP contents were associated with increased NDF content when processing time was increased during dry heating of canola meal at 125 and $145^{\circ} \mathrm{C}$. In the current study, samples conditioned for $50 \mathrm{~s}$ tended to have a lower NDF content than those conditioned for $75 \mathrm{~s}(P$ $<0.10)$. Reduced SCP and increased NDICP contents were likely due to the formation of crosslinks between protein and fiber during the pelleting process (Goelema, 1999).

The ADICP content of samples, with an average of $4.5 \% \mathrm{CP}$, was not affected in the current study. McKinnon et al. (1995) observed increased ADICP and NDICP when canola meal was heated from 125 to $145^{\circ} \mathrm{C}$. They assumed that increased processing temperature was responsible for this increase. Nia and
Ingalls (1992) observed that ADICP and NDICP were increased by increasing heating time during autoclaving at $127^{\circ} \mathrm{C}$. Mustafa et al. (2000) indicated that NDICP and ADICP were increased and SCP was decreased after desolventizing-toasting (103 to $\left.107^{\circ} \mathrm{C}\right)$. In addition, ADICP content can reflect heat-damaged indigestible protein in feed materials (McKinnon et al., 1995). McKinnon et al. (1995) also observed decreased intestinal $\mathrm{CP}$ digestibility because of increased ADICP in canola meal. During canola processing, canola meal is heated up to $120^{\circ} \mathrm{C}$, which results in protein denaturation and the Maillard reaction (Newkirk, 2009). Canola protein was not damaged further in our study.

\section{Effects of Conditioning Temperature and Time on Energy Values}

Effects of temperature and time of conditioning during the pelleting process on energy values of canola meal are presented in Table 3. To summarize, energy values were not affected by conditioning temperature and time. No significant effect of conditioning time, temperature, or their interaction on TDN (tdNFC, tdCP, tdNDF, and tdFA) was found. In addition, the unprocessed mash was not significantly different in TDN from pellets processed under different conditioning temperatures and time $(P>0.05)$. Total digestible nutrients $\left(\mathrm{TDN}_{1 \times}\right)$ and predicted energy values $\left(\mathrm{DE}_{1 \times}\right.$, $\mathrm{DEp}_{3 \times}, \mathrm{MEp}_{3 \times}, \mathrm{NELp}_{3 \times}, \mathrm{ME}, \mathrm{NE}_{\mathrm{M}}$, and $\left.\mathrm{NE}_{\mathrm{G}}\right)$ were not affected by the pelleting process in the current study $(P$ $>0.05$ ). Additionally, the unprocessed mash had similar estimated energy values to the pellets. Therefore, pelleting under different conditioning temperatures and time in our study did not change TDN or estimated energy values of canola meal.

\section{Effects of Conditioning Temperature and Time on Protein and Carbohydrate Fraction Profiles}

Table 4 shows the $\mathrm{CHO}$ and protein fractions of all samples. Conditioning time had a negative effect on PA2 fraction $(P<0.05)$. Samples conditioned for $50 \mathrm{~s}$ exhibited a higher PA2 content that those conditioned for 75 s (21.7 vs. $20.1 \%$ CP). Samples conditioned for 
HUANG ET AL.

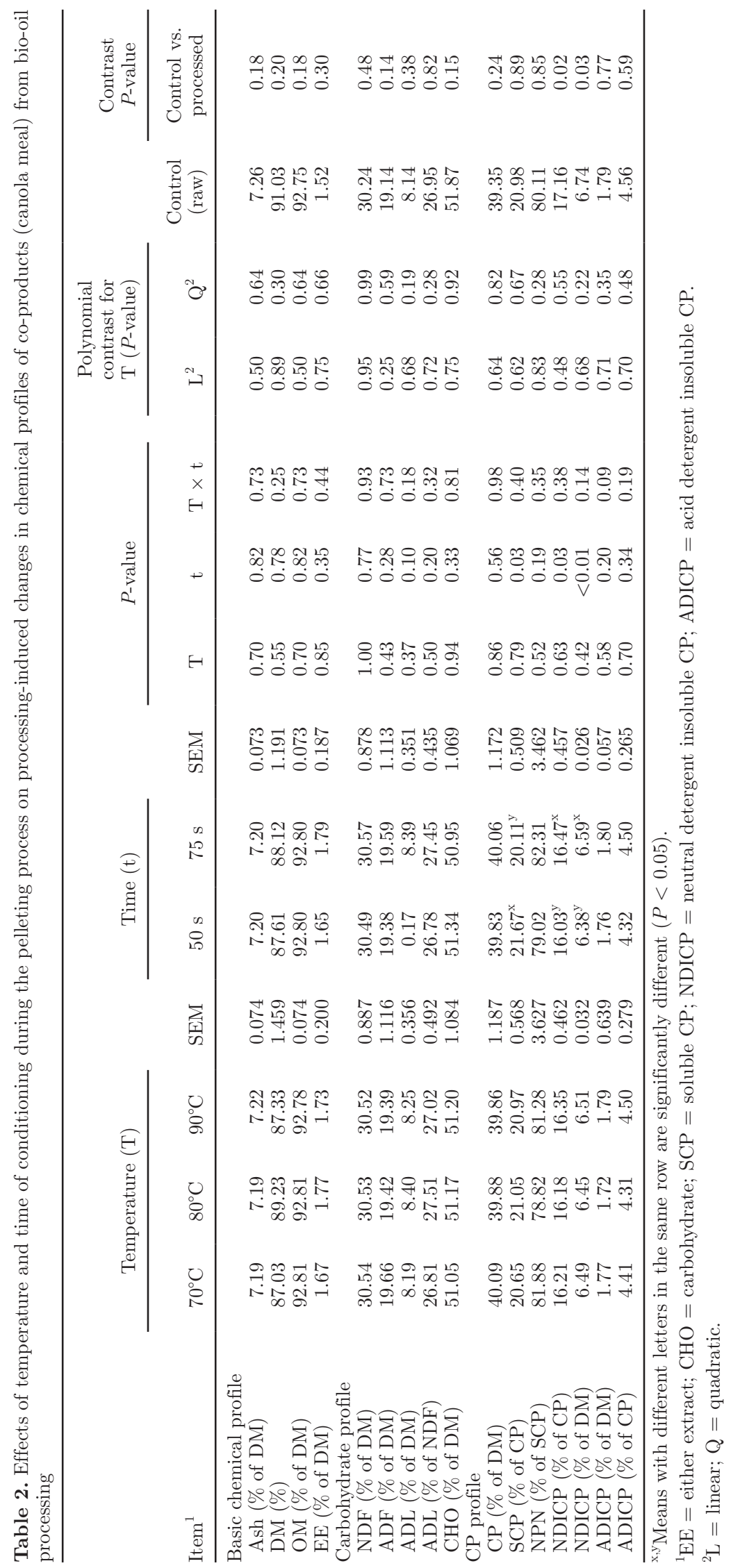


PELLETING-INDUCED MOLECULAR STRUCTURE CHANGES

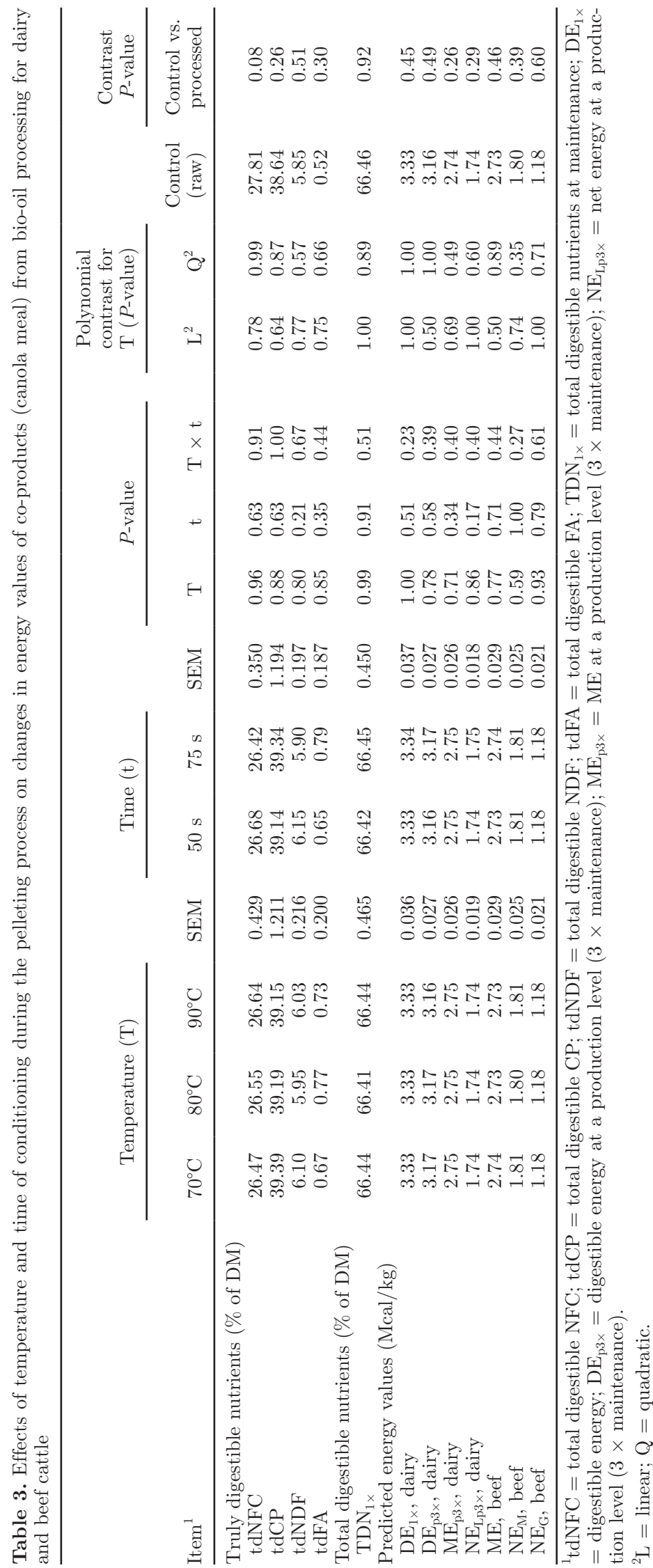


75 s tended toward a higher PB1 content than those conditioned for $50 \mathrm{~s}(63.4$ vs. $62.3 \% \mathrm{CP}, P<0.10)$. The PB2 fraction was significantly affected by the interaction of conditioning time and temperature $(P<0.05)$. At a conditioning time of $50 \mathrm{~s}$, samples conditioned at $70^{\circ} \mathrm{C}$ were not different from those conditioned at $80^{\circ} \mathrm{C}$ in $\mathrm{PB} 2$, but samples conditioned $90^{\circ} \mathrm{C}$ had higher $\mathrm{PB} 2$ than those conditioned at $80^{\circ} \mathrm{C}$. At a conditioning time of $75 \mathrm{~s}$, samples conditioned at $70^{\circ} \mathrm{C}$ were not different from those conditioned at 80 or $90^{\circ} \mathrm{C}$ in $\mathrm{PB} 2$. However, samples conditioned at $80^{\circ} \mathrm{C}$ were higher in $\mathrm{PB} 2$ than those conditioned at $90^{\circ} \mathrm{C}$ (Figure 2). The unprocessed mash had a higher PB2 content than pelleted samples $(P<0.05)$, demonstrating that a pelleting process with relatively low temperatures negatively affected PB2. We detected no difference in PC content among all samples.

The total $\mathrm{CHO}$ content of canola meal was not affected when pelleting under different conditioning temperatures and time. We found no significant effect of conditioning temperature, time, or their interaction on carbohydrate fractions, in terms of CA4, CB2, CB3, and CC. Pelleted samples were not different from the unprocessed mash in regards to carbohydrate fractions either. Theodoridou and $\mathrm{Yu}$ (2013b) observed that CA and $\mathrm{CB}$ were decreased but $\mathrm{CC}$ was increased when canola presscake was desolventizing-toasted. However, pelleting under different conditioning temperatures and time had no effect on carbohydrate fractions of canola meal in our study.

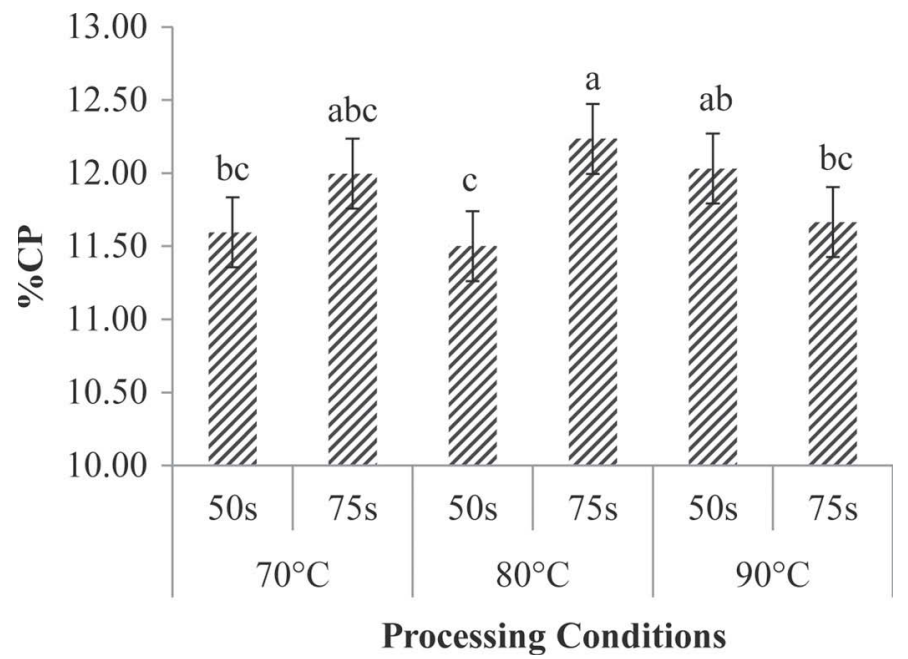

Figure 2. Effect of interaction of conditioning temperature and time on PB2 content of co-product (canola meal) pellets. Bars with different letters are significantly different $(P<0.05)$.

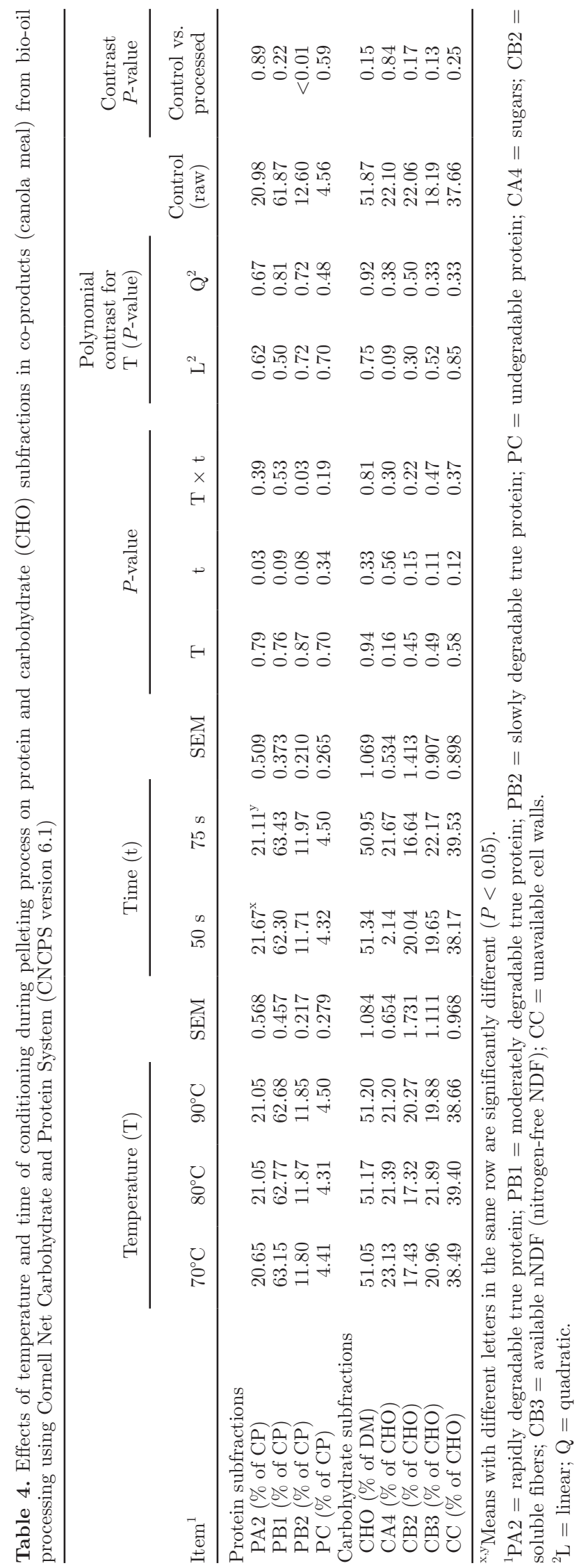

Journal of Dairy Science Vol. 98 No. 7, 2015 


\section{Effects of Conditioning Temperature and Time on Rumen Degradable and Undegradable Contents of Protein and Carbohydrate}

Effects of temperature and time of conditioning during the pelleting on rumen degradable (RD) and rumen undegradable (RU) fractions of protein and carbohydrate are shown in Table 5. The samples conditioned for $50 \mathrm{~s}$ differed from those conditioned for 75 s $(P<0.05)$ : higher RDPA2 and RUPA2 (6.6 vs. $6.2 \%$ $\mathrm{DM}, 2.0$ vs. $1.9 \% \mathrm{DM}$, respectively). Although altering conditioning conditions did not change RDPB2 and RUPB2 in canola meal pellets, the unprocessed mash tended to have higher RDPB2 and RUPB2 contents than the pellets $(P<0.10)$. We observed no significant effect of conditioning temperature, time, or their interaction on rumen degraded and escaped fractions of carbohydrates. None of the samples differed significantly from each other in fractions of rumen degradable and undegradable $\mathrm{CHO}$, in terms of RDCA4, RDCA2, RDCB3, RUCA4, RUCA2, RUCB3, as well as total rumen degraded and escaped CHO (TRDC and TRUCC).

\section{Effects of Conditioning Temperature and Time on Protein Molecular Structure Changes}

Effects of conditioning temperature and time on protein molecular structure in co-products from bio-oil processing are shown in Table 6 . In the protein amide spectral region $\left(\sim 1,481-1,718 \mathrm{~cm}^{-1}\right)$, the amide I height and area in canola meal pellets were not affected by conditioning temperature, time, or their interaction. In addition, the unprocessed mash was not significantly different from pellets in terms of amide I height and area. Conditioning time and conditioning temperature showed significant effects on amide II area, but the interaction was not significant. Samples conditioned at $70^{\circ} \mathrm{C}$ had the highest amide II area among samples conditioned at different temperatures. Samples conditioned for $50 \mathrm{~s}$ were lower in amide II area than those conditioned for $75 \mathrm{~s}(1.92$ vs. $2.10 ; P<0.05)$. The interaction of conditioning temperature and time on amide II peak height was not significant $(P>0.05)$. Conditioning temperature had a negative effect on amide II height so that the samples conditioned at $70^{\circ} \mathrm{C}$ were highest in amide II peak $(P<0.01)$. Conditioning time had a positive effect on amide II height $(P<$ $0.01)$ : the samples conditioned for $75 \mathrm{~s}$ had a higher amide II peak height than those conditioned for $50 \mathrm{~s}$ (0.041 vs. 0.036). In infrared spectroscopy, obtaining precise values of protein secondary structural profiles for every sample is impossible. However, spectral data from different samples are comparable if samples are processed in similar ways ( $\mathrm{Yu}, 2006)$. In addition, the sensitivity of mid-infrared spectroscopy will result in differences in spectra measurement due to differences in methodologies, selected regions, and baselines among studies (Yu, 2006; Doiron et al., 2009).

The ratios of amide I height to amide II height and amide I area to amide II area were positively affected by conditioning temperature $(P<0.05)$ but negatively affected by conditioning time $(P<0.001)$. The interaction was not significant. Samples conditioned at $90^{\circ} \mathrm{C}$ had the highest ratios of amide I height to amide II height $(2.54, P<0.05)$ and amide I area to amide II area $(1.45, P<0.05)$ compared with those conditioned at $70^{\circ} \mathrm{C}$ and $80^{\circ} \mathrm{C}$. Samples conditioned for $50 \mathrm{~s}$ were higher than those conditioned for $75 \mathrm{~s}$ in ratio of amide I height to amide II height (1.56 vs. 1.41) and ratio of amide I area to amide II area (2.48 vs. 2.35). Compared with the unprocessed mash, pellets exhibited higher values of these 2 ratios $(P<0.05)$. The ratio of amide I to amide II can be significantly affected by feed materials, heat processing, and gene transformation (Liu et al., 2012). Theodoridou and Yu (2013b) observed that canola meal had a lower amide I to amide II area ratio than canola presscake, indicating that the area ratio was reduced after desolventizing-toasting during canola processing. However, Samadi et al. (2013) indicated that no difference in the area ratio of amide I to amide II was observed when autoclaved $\left(121^{\circ} \mathrm{C} ; 1 \mathrm{~h}\right)$ and roasted $\left(120^{\circ} \mathrm{C} ; 1 \mathrm{~h}\right)$ canola seeds were compared with unprocessed canola seeds.

No significant effect of conditioning temperature, time, or their interaction on $\alpha$-helix height and $\beta$-sheet height was observed. The difference between the unprocessed mash and the pellets was not significant. With respect to the ratio of $\alpha$-helix to $\beta$-sheet, conditioning temperature, time, or their interaction did not exhibit a significant effect $(P>0.05)$. However, the unprocessed mash was significantly different from pellets with a lower ratio of $\alpha$-helix to $\beta$-sheet $(P<0.05)$. Doiron et al. (2009) indicated that changes in nutrient values of feeds were associated with changes in the ratio of $\alpha$-helix to $\beta$-sheet. Yu (2005b) indicated that a lower protein value was associated with the increased content of $\beta$-sheet structure, which reduces accessibility of gastrointestinal enzymes for protein. Yu et al. (2004) observed that raw feather with a high protein content of $84 \%$ had a low protein digestibility of $5 \%$. This was partially because the high level of $\beta$-sheet was negatively correlated with protein digestibility (Yu et al., 2004). Theodoridou and Yu (2013a) found that canola meal had lower $\alpha$-helix and $\beta$-sheet heights than canola presscake. In their study, $\alpha$-helix height was positively correlated with ADICP, indicating that a higher $\alpha$-helix height may result in a lower protein digestibility. They also found that the ratio of $\alpha$-helix 
HUANG ET AL.

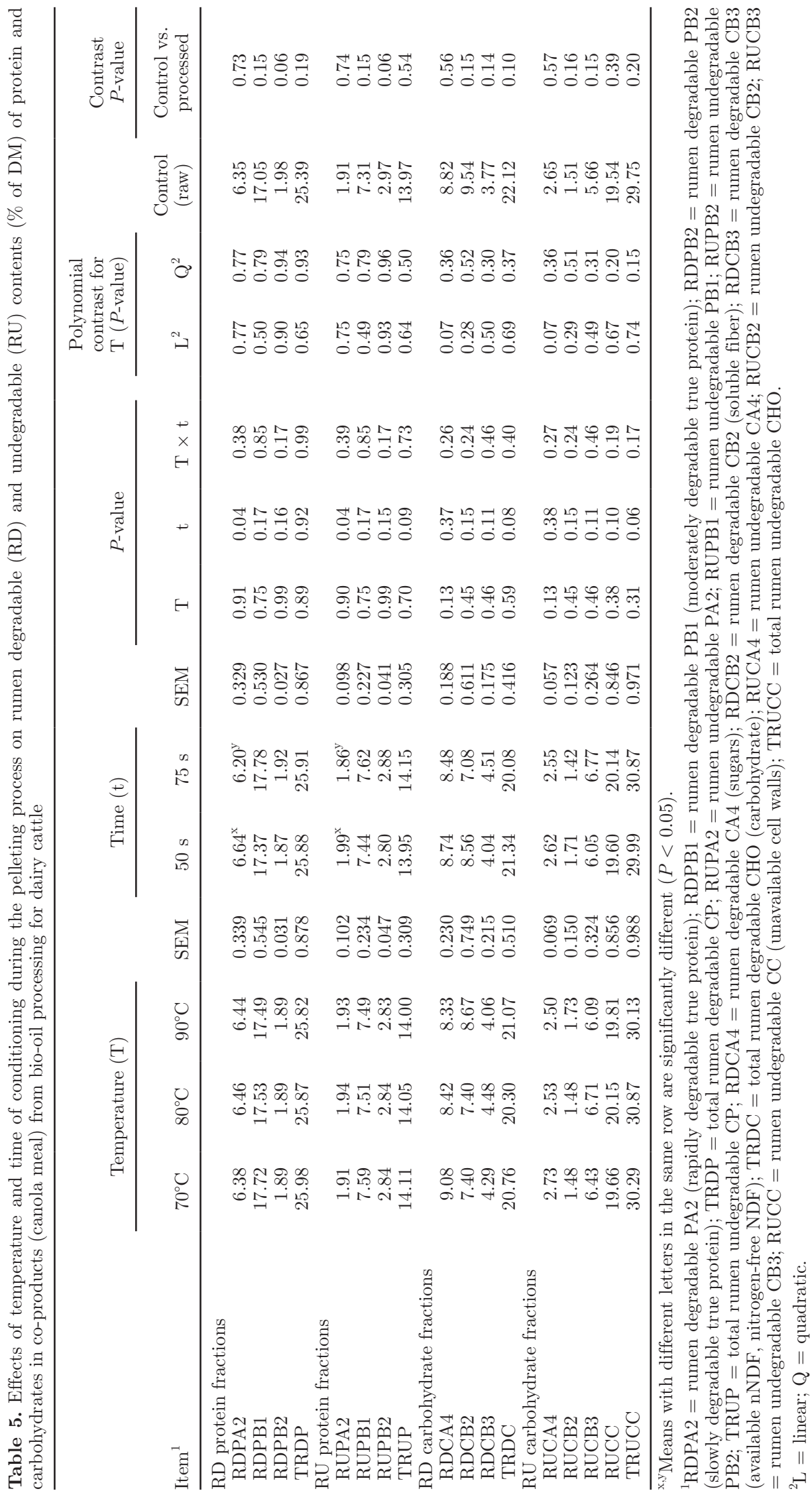


to $\beta$-sheet played an important role in determining ruminal and intestinal digestion of protein. Yu (2005a) indicated that an increase in $\beta$-sheet height after heat treatment was likely due to the protein aggregation required to form intermolecular $\beta$-sheet structures. Yu (2005b) reported that reduced $\alpha$-helix and increased $\beta$-sheet were observed in roasted golden flax seeds. In addition, the ratio of $\alpha$-helix to $\beta$-sheet was decreased from 1.28 to 0.73. In Doiron et al. (2009), an increased ratio of $\alpha$-helix to $\beta$-sheet was observed in the endosperm area of autoclaved flaxseed $\left(120^{\circ} \mathrm{C} ; 20,40\right.$, and $60 \mathrm{~min}$ ). In addition, the height ratio of $\alpha$-helix to $\beta$-sheet correlated with protein profiles and digestive characteristics. Samadi and Yu (2011) reported that autoclaving $\left(120^{\circ} \mathrm{C} ; 1 \mathrm{~h}\right)$ reduced $\alpha$-helix and $\beta$-sheet heights of soybean seeds; therefore, the ratio of $\alpha$-helix to $\beta$-sheet in soybean seed was reduced. Samadi et al. (2013) observed no difference in $\alpha$-helix and $\beta$-sheet heights in raw, autoclaved, and roasted canola seeds. However, the ratio of $\alpha$-helix to $\beta$-sheet, which correlated with rumen degradation and intestinal digestion characteristics of protein, decreased with autoclaving at $121^{\circ} \mathrm{C}$ for $60 \mathrm{~min}$ and increased with roasting at $120^{\circ} \mathrm{C}$ for $60 \mathrm{~min}$. Peng et al. (2014b) reported that the ratio of $\alpha$-helix to $\beta$-sheet in camelina seeds was decreased with autoclaving at $120^{\circ} \mathrm{C}$ for $60 \mathrm{~min}$, and this was associated with decreased rumen degradation but increased intestinal digestion of protein. In our study, the lower ratio of $\alpha$-helix to $\beta$-sheet was observed in the unprocessed mash, which was in accordance with the higher rumen degradation and lower intestinal digestion of protein found in the pelleted samples. Again, the structural stability of a protein is sensitive to its environmental conditions (Goelema, 1999). It should be kept in mind that the combination of processing conditions such as temperature, time, and pressure could affect the protein's inherent structure.

In term of industry implications in this study, changes in the detailed data on chemical and nutrient profiles, TDN, energy values, CNCPS protein and CHO fractions, and nutrient supply of canola meal to dairy cattle induced by pelleting conditioning temperature and time are important in ration formulation in feed mills. This will improve the accuracy in predicting nutrient supply and utilization when diets contain the co-product pelleted under different conditions.

\section{CONCLUSIONS}

Different conditioning temperatures (70, 80, and $90^{\circ} \mathrm{C}$ ) and time (50 and $75 \mathrm{~s}$ ) affected nutrient profiles and protein fractions of co-products from bio-oil processing (canola meal). Increasing conditioning time reduced SCP and increased NDICP contents of the pel- 
leted co-products. However, the total protein content was not changed. In regards to protein fraction profiles, PA2 decreased with increasing conditioning time during the pelleting process. Conditioning temperature and time had an interaction effect on PB2 content. However, changes in temperature and time during the conditioning stage did not alter $\mathrm{CHO}$ profiles, TDN, or predicted energy profiles. Univariate molecular structure analyses showed that pelleting altered inherent protein molecular structures of co-products from bio-oil processing.

\section{ACKNOWLEDGMENTS}

The authors thank Zhiyuan Niu (Department of Animal and Poultry Science, University of Saskatchewan) and Louis L. Roth (Department of Chemical and Biological Engineering, College of Engineering, University of Saskatchewan) for their helpful assistance in the project, and Tom Scott and Fiona Buchanan (both of Department of Animal and Poultry Science, University of Saskatchewan) for their valuable suggestions and discussion. Financial support for SRP Research Chair (Peiqiang Yu) from the Saskatchewan Ministry of Agriculture Strategic Research Chair Program in Feeds R\&D, the Natural Sciences and Engineering Research Council of Canada (NSERC), the Thousand-Talent People Research Program and University Innovation Team "Veterinary Biotechnology" (TD12-5019, Tianjin), the Saskatchewan Agriculture Development Fund (ADF, Saskatchewan, Canada), the SaskCanola (Saskatoon, SK, Canada), the SaskMilk (Regina, SK, Canada), the Saskatchewan Forage Network (SNK, Saskatoon, SK, Canada), and Western Grain Research Foundation (WGRF, Saskatoon, SK, Canada) is acknowledged.

\section{REFERENCES}

Abdollahi, M. R., V. Ravindran, and B. Svihus. 2013. Pelleting of broiler diets: An overview with emphasis on pellet quality and nutritional value. Anim. Feed Sci. Technol. 179:1-23.

AOAC (Association of Official Analytical Chemists). 1990. Official Methods of Analysis. 15th ed. AOAC, Washington, DC.

Doiron, K. J., P. Yu, C. R. Christensen, D. A. Christensen, and J. J. McKinnon. 2009. Detecting molecular changes in Vimy flaxseed protein structure using synchrotron FTIRM and DRIFT spectroscopic techniques: Structural and biochemical characterization. J. Spectrosc. 23:307-322.

Fairchild, F., and D. Greer. 1999. Pelleting with precise mixer moisture control. Feed Int. 20:32-36.

Falk, D. 1985. Pelleting cost centre. Pages 167-190 in Feed Manufacturing Technology III. R. R. Mcellhiney, ed. American Feed Manufacturers Association, Arlington, VA.

Goelema, J. O. 1999. Processing of legume seeds: Effects on digestive behaviour in dairy cows. PhD Thesis. Wageningen University, Wageningen, the Netherlands.

Higgs, R. J., L. E. Chase, D. A. Ross, and M. E. Van Amburgh. 2012 Evaluating and refining the CNCPS feed library using commercial laboratory feed databases. Accessed May 20, 2014. http://www. ansci.cornell.edu/pdfs/cnc2012_Higgs.txt.pdf.

Jackson, M., and H. H. Mantsch. 1995. The use and misuse of FTIR spectroscopy in the determination of protein structure. Crit. Rev. Biochem. Mol. Biol. 30:95-120.

Jackson, M., and H. H. Mantsch. 2000. Infrared spectroscopy ex vivo tissue analysis. Pages 131-156 in Encyclopedia of Analytical Chemistry. R. A. Meyers, ed. Wiley, Chichester, UK.

Licitra, G., T. M. Hernandez, and P. J. van Soest. 1996. Standardization of procedures for nitrogen fractionation of ruminant feeds. Anim. Sci. Feed. Technol. 57:347-358.

Liu, B., J. J. McKinnon, P. Thacker, and P. Yu. 2012. Molecular structure and metabolic characteristics of the proteins and energy in triticale grains and dried distillers grains with solubles for dairy cattle. J. Agric. Food Chem. 60:10064-10074.

McKinnon, J. J., J. A. Olubobokun, A. Mustafa, R. D. H. Cohen, and D. A. Christensen. 1995. Influence of dry heat treatment of canola meal on site and extent of nutrient disappearance in ruminants. Anim. Feed Sci. Technol. 56:243-252.

Moritz, J. S., and K. G. S. Lilly. 2010. Production strategies and feeding opportunities for pellets of high quality. Pages 85-90 in Proc. 8th Annu. Mid-Atlantic Nutr. Conf., University of Maryland, College Park. University of Maryland, Maryland Feed Ind. Council, College Park.

Mustafa, A. F., D. A. Christensen, J. J. McKinnon, and R. Newkirk 2000. Effects of stage of processing of canola seed on chemical composition and in vitro protein degradability of canola meal and intermediate products. Can. J. Anim. Sci. 80:211-214.

Newkirk, R. 2009. Canola Meal Feed Industry Guide. 4th ed. Accessed May 20, 2014. http://www.canolacouncil.org/media/516716/canola_meal_feed_guide_english.pdf.

Nia, S. M., and J. R. Ingalls. 1992. Effect of heating on canola meal protein degradation in the rumen and digestion in the lower gastrointestinal tract of steers. Can. J. Anim. Sci. 72:83-88.

NRC. 1996. Nutrient Requirements of Beef Cattle. 7th ed. Natl. Acad. Sci., Washington, DC.

NRC. 2001. Nutrient Requirements of Dairy Cattle. 7th rev. ed. Natl. Acad. Sci., Washington, DC.

Peng, Q., N. A. Khan, Z. Wang, and P. Yu. 2014b. Moist and dry heating-induced changes in protein molecular structure, protein subfractions, and nutrient profiles in camelina seeds. J. Dairy Sci. $97: 446-457$.

Peng, Q., Z. Wang, X. Zhang, and P. Yu. 2014a. Common prairie feeds with different soluble and insoluble fractions used for CPM diet formulation in dairy cattle: Impact of carbohydrate-protein matrix structure on protein and other primary nutrient digestion. Spectrochim. Acta A Mol. Biomol. Spectrosc. 121:14-22.

Roe, M. B., C. J. Sniffen, and L. E. Chase. 1990. Techniques for measuring protein fractions in feedstuffs, Pages 81-88 in Proc. Cornell Nutrition Conf. Department of Animal Science, Cornell University, Ithaca, NY.

Samadi, K. Theodoridou, and P. Yu. 2013. Detect the sensitivity and response of protein molecular structure of whole canola seed (yellow and brown) to different heat processing methods and relation to protein utilization and availability using ATR-FT/IR molecular spectroscopy with chemometrics. Spectrochim. Acta A Mol. Biomol. Spectrosc. 105:304-313.

Samadi, and P. Yu. 2011. Dry and moist heating-induced changes in protein molecular structure, protein subfraction, and nutrient profiles in soybeans. J. Dairy Sci. 94:6092-6102.

Skoch, E. R., K. C. Behnke, C. W. Deyoe, and S. F. Binder. 1981. The effect of steam-conditioning rate on the pelleting process. Anim. Feed Sci. Technol. 6:83-90.

Theodoridou, K., and P. Yu. 2013a. Application potential of ATR-FT/ IR molecular spectroscopy in animal nutrition: Revelation of protein molecular structures of canola meal and presscake, as affected by heat-processing methods, in relationship with their protein digestive behavior and utilization for dairy cattle. J. Agric. Food Chem. 61:5449-5458.

Theodoridou, K., and P. Yu. 2013b. Effect of processing conditions on the nutritive value of canola meal and presscake. Comparison of 
the yellow and brown-seeded canola meal with the brown-seeded canola presscake. J. Sci. Food Agric. 93:1986-1995.

Thomas, M., and A. F. B. van der Poel. 1996. Physical quality of pelleted animal feed 1. Criteria for pellet quality. Anim. Feed Sci. Technol. 61:89-112.

Thomas, M., D. J. Van Zuilichem, and A. F. B. Van der Poel. 1997. Physical quality of pelleted animal feed. 2. Contribution of processes and its conditions. Anim. Feed Sci. Technol. 64:173-192.

Tylutki, T. P., D. G. Fox, V. M. Durbal, L. O. Tedeschi, J. B. Russell, M. E. Van Amburgh, and A. N. Pell. 2008. Cornell Net Carbohydrate and Protein System: A model for precision feeding of dairy cattle. Anim. Feed Sci. Technol. 143:174-202.

Van Amburgh, M. E., L. E. Chase, T. R. Overton, D. A. Ross, E. B. Recktenwald, R. J. Higgs, and T. P. Tylutki. 2010. Updates to the Cornell Net Carbohydrate and Protein System v6. 1 and implications for ration formulation. In Proc. Cornell Nutrition Conf. for Feed Manufacturers. Accessed May 19, 2014. http://ansci1.abc. cornell.edu/cnconf/2010proceedings/CNC2010.17.VanAmburgh. pdf.

Van Amburgh, M. E., A. Foskolos, E. A. Collao-Saenz, R. J. Higgs, and D. A. Ross. 2013. Updating the CNCPS feed library with new feed amino acid profiles and efficiencies of use: Evaluation of model predictions-version. Accessed May 19, 2014. http://www. ansci.cornell.edu/pdfs/CNC2013_VanAmburgh_m.pdf.

Van Soest, P. 1989. On the digestibility of bound $\mathrm{N}$ in distillers grains: A reanalysis. Pages 127-136 in Proc. Cornell Nutr. Conf., Syracuse, NY. Cornell University, Ithaca, NY.

Van Soest, P. J., J. B. Robertson, and B. A. Lewis. 1991. Methods for dietary fiber, neutral detergent fiber and nonstarch polysaccharides in relation to animal nutrition. J. Dairy Sci. 74:3583-3597.

Xin, H., and P. Yu. 2013a. Using ATR-FT/IR to detect carbohydraterelated molecular structure features of carinata meal and their in situ residues of ruminal fermentation in comparison with canola meal. Spectrochim. Acta A Mol. Biomol. Spectrosc. 114:599-606.
Xin, H., and P. Yu. 2013b. Detect changes in protein structure of carinata meal during rumen fermentation in relation to basic chemical profile and comparison with canola meal using ATR-FT/IR molecular spectroscopy with chemometrics. Spectrochim Acta A Mol. Biomol. Spectrosc. 112:318-325.

Yang, L., D. A. Christensen, J. J. McKinnon, A. D. Beattie, H. Xin, and P. Yu. 2013b. Investigating the molecular structural features of hulless barley (Hordeum vulgare L.) in relation to metabolic characteristics using synchrotron-based Fourier transform infrared microspectroscopy. J. Agric. Food Chem. 61:11250-11260.

Yu, P. 2004. Application of advanced synchrotron radiation-based Fourier transform infrared (SR-FTIR) microspectroscopy to animal nutrition and feed science: A novel approach. Br. J. Nutr. 92:869-885.

$\mathrm{Yu}, \mathrm{P} .2005 \mathrm{a}$. Prediction of protein supply to ruminants from concentrates: Comparison of the NRC-2001 model with the DVE/OEB system. J. Sci. Food Agric. 85:527-538.

Yu, P. 2005b. Protein secondary structures ( $\alpha$-helix and $\beta$-sheet) at a cellular level and protein fractions in relation to rumen degradation behaviours of protein: A new approach. Br. J. Nutr. 94:655-665.

Yu, P. 2006. An emerging method for rapid characterization of feed structures and feed component matrix at a cellular level and relation to feed quality and nutritive value. Arch. Anim. Nutr. 60:229-244.

Yu, P. 2010. Plant-based food and feed protein structure changes induced by gene-transformation, heating and bio-ethanol processing: A novel synchrotron-based molecular structure and nutrition research program. Mol. Nutr. Food Res. 54:1535-1545.

$\mathrm{Yu}$, P., J. J. McKinnon, C. R. Christensen, and D. A. Christensen. 2004. Using synchrotron transmission FTIR microspectroscopy as a rapid, direct and non-destructive analytical technique to reveal molecular microstructural-chemical features within tissue in grain barley. J. Agric. Food Chem. 52:1484-1494. 